\title{
SISTEM INFORMASI KREDIT SAHABAT PADA BADAN USAHA MILIK DESA (BUMDES) DESA SEMAMUNG BERBASIS WEB
}

\author{
Jundi khoirullah ${ }^{1)}$, Rodianto ${ }^{2)}$, Yana Karisma ${ }^{3)}$ \\ ${ }^{1)}$ Mahasiswa Informatika, Universitas Teknologi Sumbawa \\ ${ }^{2,3}$ Dosen Informatika, Universitas Teknologi Sumbawa \\ Email: khoirullahjundi@gmail.com ${ }^{1}, \underline{\text { rodianto@ }}$ uts.ac.id $^{2}$, yana.karisma@ uts.ac.id ${ }^{3}$
}

\begin{abstract}
ABSTRAK
Salah satu upaya percepatan perekonomian desa adalah ketersediaan modal usaha. Setiap desa memiliki suatu badan usaha yang diberi nama Badan Usaha Milik Desa (BUMDes). Badan usaha ini memiliki salah satu program kerja yaitu "Kredit Sahabat (KRABAT)" yang memberikan modal bagi masyarakat. Hal ini dilakukan dalam rangka mewujudkan program desa tanpa rentenir. Dengan menerapkan teknologi informasi yang tepat guna dapat membantu meningkatkan efektifitas dalam suatu pekerjaan. Sistem Informasi Kredit Sahabat Pada Badan Usaha Milik Desa (Bumdes) Desa Semamung Berbasis Web ini akan dibangun dengan menggunakan bahasa pemrograman PHP, pembangunan perangkat lunak menggunakan waterfall, database MySQL, dan IDE Sublimetext. Sistem ini dapat digunakan untuk mempermudah pihak manajemen BUMDes Sahabat Desa Semamung dalam proses pencatatan dan pencarian data masyarakat yang melakukan peminjaman baik dari jumlah pinjaman yang diajukan maupun sisa pinjaman yang telah dibayarkan dan penyimpanan baik dari jumlah yang disimpan maupun diambil dari pihak BUMDes Sahabat Desa Semamung dalam skala penyimpanan yang cukup besar. Sistem ini dapat mempermudah petugas dalam menjalankan proses pengajuan pinjaman atau kredit, simpanan, dan angsuran pada proses Kredit di BUMDes Sahabat Desa Semamung karena menggunakan sistem terkomputerisasi. Dengan demikian proses pendataan dan penghitungan kredit sahabat pada BUMDes Desa Semamung dapat dilakukan dengan efektif karena proses pendataan dan penghitungan tidak lagi mencatat secara manual.
\end{abstract}

Kata Kunci : BUMDes, Web, PHP, Waterfall, Sublime

\begin{abstract}
One of the efforts the acceleration of the economy of the village is the availability of venture capital. Each village has a business entity that is named the village owned enterprises (BUMDes). A business entity has one work program, namely "credit Companions (KRABAT)" which provides capital for the community. This is done in order to realize the program villages without the moneylenders. By applying the appropriate information technology can help improve effectiveness in a given job. Credit information system's best friend On the villageowned enterprise (Bumdes) of this Web-based Semamung will be built using the PHP programming language, software development using a waterfall, a MySQL database, and Sublimetext. This system can be used to facilitate the management of the village's best friend BUMDes Semamung in the process of recording data and search communities that do the borrowing either from the loan amount submitted as well as the rest of the loans have been paid and good storage of the amount deposited or taken from the village of Semamung in the companion of BUMDes-scale storage. This system can make the officer in carrying out the process of filing a loan or credit, savings, and installment Credit process in BUMDes village of Semamung best friend because it uses a computerized system. Thus the process of logging and counting KRABAT on BUMDes village of Semamung can be carried out effectively because of logging and counting process were no longer recorded manually.
\end{abstract}

Keywords: BUMDes, Web, PHP, Waterfall, Sublime 


\section{PENDAHULUAN}

\section{Latar Belakang}

Salah satu upaya untuk percepatan perekonomian desa adalah ketersediaan modal usaha. BUMDes memiliki salah satu program kerja yaitu "Kredit Sahabat (KRABAT)", yang memberikan modal bagi masyarakat yang bekerja sebagai petani yang memiliki sawah yang dapat ditanami namun tidak memiliki modal untuk melakukan proses penanaman padi. Oleh karena itu program KRABAT ini menjadi salah satu langkah dalam meningkatkan perekonomian desa dengan memberikan kredit dengan bunga hingga $0 \%$ hal ini dilakukan dalam rangka mewujudkan program desa tanpa rentenir.

Permasalahan yang kerap terjadi di BUMDes SAHABAT Desa Semamung yaitu pada proses pemberian KRABAT masih dilakukan secara konvensional dengan cara mencatatat pada buku besar, sehingga berimbas pada penumpukkan data dan kesalahan pencatatan yang menyebabkan proses pencarian penerima KRABAT memakan waktu yang lama. Dalam proses pencatatan laporan pembayaran maupun penyimpanan masyarakat yang mengajukan program KRABAT ditemukan juga dua masalah umum yakni kreditur tidak dapat melakukan pelunasan pinjaman berdasarkan waktu yang telah ditentukan, sehingga masih terjadi kesalahan jumlah sisa pinjman serta simpanan dalam buku besar tersebut.

Berdasarkan dari masalah tersebut, penulis memberikan suatu tawaran solusi dengan merancang "Sistem Informasi Kredit Sahabat pada BUMDes Sahabat Desa Semamung Berbasis web". Sistem ini dapat digunakan untuk mempermudah pihak manajemen BUMDes Sahabat Desa Semamung dalam proses pencatatan dan pencarian data masyarakat yang melakukan peminjaman baik dari jumlah pinjaman yang diajukan maupun sisa pinjaman yang telah dibayarkan dan penyimpanan baik dari jumlah yang disimpan maupun diambil dari pihak BUMDes Sahabat Desa Semamung dalam skala penyimpanan yang cukup besar.

\section{Rumusan Masalah}

Merujuk pada latar belakang di atas penulis mengidentifikasi beberapa permasalahan yang kerap muncul diantaranya:

1. Rawan terjadinya kesalahan pencatatan yang berpengaruh terhadap pencarian data penerima KRABAT yang masih ditulis dengan cara mencatatat dibuku besar.

2. Rumitnya proses pendataan, dan sering terjadi ketidaksinkronan nominal tabungan maupun sisa pinjaman, yang berimbas pada penumpukkan data dan kesalahan pencatatan sehingga proses pencarian data KRABAT menjadi tertunda.

3. Perlu adanya sistem informasi berbasis web yang mampu mengelola program KRABAT.

Berdasarkan identifikasi masalah tersebut maka ditarik suatu inti permasalahan yaitu"Bagaimana Membuat Sistem Informasi Kredit Sahabat pada BUMDes Sahabat Desa Semamung Berbasis Web?".

\section{Batasan Masalah}

Adapun batasan masalah dari sistem tersebut yaitu sebagai berikut:

1. Analisis kebutuhan data dilakukan di BUMDes Desa Semamung.

2. Sistem informasi ini hanya mengelola data kredit sahabat saja. Dimana pengelolaan kredit sahabat meliputi, penambahan nasabah, penyimpanan atau tabungan dan data peminjaman. Sedangkan untuk data peminjamannya meliputi cicilan dan setoran atau angsuran pinjaman.

3. Hanya dikhususkan untuk pengurus BUMDes Desa Semamung.

4. Pinjaman yang dilakukan oleh nasabah hanya dapat dilakukan setelah anggota terdaftar.

5. Sistem informasi yang dibuat menggunakan bahasa pemrograman $\mathrm{php}$ dan databasenya dibuat dengan menggunakan bahasa pemograman mysql dengan menggunakan server xampp.

\section{Tujuan Penelitian}

Adapun tujuan dari penelitian ini adalah menganalisa dan merancang Sistem Informasi Kredit Sahabat pada BUMDes Sahabat Desa Semamung. Sedangkan secara khusus tujuan dari pembuatan tugas akhir ini adalah sebagai berikut:

1. Merekomendasikan suatu rancangan sistem pengolahan data berbasis web.

2. Sistem informasi ini akan digunakan untuk mendapatkan informasi pengolahan data kredit yang tepat dan akurat, sehingga bermanfaat dan meningkatkan kinerja bagi BUMDes Sahabat Desa Semamung.

3. Mengurangi terjadinya kesalahan pencatatan data Kredit maupun data penyimpanan seperti tabungan dan pinjaman.

\section{LANDASAN TEORI}

\section{Definisi Badan Usaha Milik Desa (BUMDes)}

Menurut Pusat Kajian Dinamika Sistem Pembangunan dalam Panduan Pendirian dan Pengelolaan BUMDes Pembangunan, P. K. D. S (2007), terdapat 7 (tujuh) ciri utama yang membedakan BUMDes dengan lembaga ekonomi komersial pada umumnya:

1. Badan usaha ini dimiliki oleh desa dan dikelola secara bersama.

2. Modal usaha bersumber dari desa (51\%) dan dari masyarakat, Disebarluaskan oleh Pimpinan Pusat Relawan Pemberdayaan Desa Nusantara atau PP RPDN (49\%) melalui penyertaan modal (saham atau andil).

3. Operasionalisasinya menggunakan falsafah bisnis yang berakar dari budaya lokal (local wisdom).

4. Bidang usaha yang dijalankan didasarkan pada potensi dan hasil informasi pasar.

5. Keuntungan yang diperoleh ditujukan untuk meningkatkan kesejahteraan anggota (penyerta modal) 
dan masyarakat melalui kebijakan desa (village policy).

6. Difasilitasi oleh Pemerintah, Pemerintah Provinsi, Pemerintah Kabupaten dan Pemerintah Desa.

7. Pelaksanaan operasionalisasi dikontrol secara bersama (Pemerintah Desa, Badan Permusyawaratan Desa (BPD), anggota)

\section{Definisi Kredit Sahabat (KRABAT)}

Menurut Dinas Pemberdayaan Masyarakat dan Desa (D.P.M.D). (2017) Salah satu permasalahan yang cukup berpengaruh dalam rangka percepatan perekonomian daerah dikabupaten Sumbawa khususnya ekonomi micro adalah ketersediaan modal usaha untuk sektor petani. Hal ini menyebabkan pembangunan ekonomi perdesaan yang ditopang oleh sektor pertanian menjadi terhambat sehingga berdampak negatif terhadap perekonomian daerah. Padahal pengembangan berbasis ekonomi diperdesaan sudah sejak lama dijalankan oleh pemerintah melalui berbagai program. Namun upaya itu belum membuahkan hasil signifikan terhadap pengembangan ekonomi masyarakat terutama masyarakat miskin. Misalnya program "Kredit Usaha Rakyat" (KUR) yang diharapkan menjadi salah satu sumber modal bagi masyarakat perdesaan dalam menjalankan usahanya, pada kenyataanya belum bisa diakses oleh masyarakat kelas bawah atau masyarakat miskin sehingga mereka lebih memilih meminjam modal di rentenir. Hal ini terlihat dari kondisi lapangan dimana sepak terjang rentenir masih cukup luas di tengah masyarakat.

\section{Sistem}

Sutabri, (2012) memaparkan bahwa definisi Sistem adalah sebagai suatu kumpulan atau himpunan dari unsur, komponen, atau variabel yang terorganisir, saling berinteraksi, saling tergantung satu sama lain, dan terpadu.

\section{Web}

Menurut Nugroho, (2004) Web adalah sekumpulan halaman web yang mampu berinteraksi dengan pengunjung, dengan sesama halaman web dan dengan berbagai sumber data yang ada di web server. Isi dari suatu halaman aplikasi web ini berbeda dari satu pengunjung ke pengunjung yang lainnya. Ini terjadi karena sisi halaman aplikasi web ditentukan oleh permintaan dari pengunjung yang tidak sama. Permintaan ini diproses oleh server dan kemudian dikirimkan ke browser. Oleh karena halaman-halaman aplikasi web lebih banyak dikerjakan di sisi server, maka teknologi ini sering juga disebut dengan web dinamis berbasiskan server. Sebagai contoh dari aplikasi web adalah PHPNuke, Mambo atau Joomla, Wordpress, PHPMyAdmin dan lain-lain).

\section{Informasi}

Sutanta, (2011) informasi merupakan hasil dari pengolahan data sehingga menjadi bentuk yang penting bagi penerimanya dan mempunyai kegunaan sebagai dasar dalam pengambilan keputusan yang dapat dirasakan akibatnya secara langsung saat itu juga atau secara tidak langsung pada saat mendatang.

\section{Hypertext Preprocessor (PHP)}

Menurut Madcoms, (2013) PHP adalah sebuah bahasa scripting yang terpasang pada HTML. Scriptscript PHP harus tersimpan dalam sebuah server dan dieksekusi atau diproses dalam server tersebut.

dokumen HTML, yang selanjutnya akan ditampilkan kembali ke web browser, karena pemrosesan program PHP dilakukan dilingkungan web server, PHP dikatakan sebagai bahasa sisi server (server-side). Oleh sebab itu, seperti yang telah dijelaskan sebelumnya, kode PHP tidak akan terlihat pada saat user memilih perintah "view Source" pada web browser yang digunakan.

\section{Structured Query Language (MySql)}

Berdasarkan pemaparan Kadir. (2014) Structured Query Language (SQL) adalah bahasa yang digunakan untuk mengakses basis data yang tergolong relasional. Sesungguhnya SQL tidak terbatas hanya untuk mengambil data (query), tetapi juga dapat dipakai untuk menciptakan tabel (CREATE), menghapus tabel (DELETE), menambahkan data ke tabel (INSERT), menghapus data di tabel $(D R O P)$, mengganti data di tabel (UPDATE), dan berbagai operasi yang lain.

\section{SublimeText}

Menurut Supono, (2016) menjelaskan bahwa Sublime text merupakan perangkat lunak text editor yang digunakan untuk membuat atau meng-edit suatu aplikasi. Sublime text mempunyai fitur plugin tambahan yang memudahkan programmer.

\section{Data Flow Diagram (DFD)}

Muslihudin,.(2016). Menjelaskan DFD adalah suatu model logika data atau proses yang dibuat untuk menggambarkan darimana asal data dan kemana tujuan data yang keluar dari sistem, dimana data disimpan, proses apa yang menghasilkan data tersebut dan interaksi antara data yang tersimpan dan proses yang dikenakan pada data tersebut

\section{Metode Pengembangan Sistem}

Menurut Jogiyanto, (2010) Metodologi Pengembangan Sistem adalah metode prosedur, konsepkonsep pekerjaan, aturan akan digunakan untuk mengembangkan suatu sistem informasi Pengembangan sistem didefinisikan sebagai sistem informasi berbasis komputer untuk menyelesaikan persoalan organisasi atau memanfaatkan kesempatan model air terjun (waterfall). Mengambil kegiatan dasar seperti spesifikasi, pengembangan, validasi, dan evolusi dan merepresentasikannya sebagai fase seperti spesifikasi persyaratan, perancangan perangkat lunak, implementasi, pengujian dan seterusnya. Adapun fase dalam pengembangan sistem dengan waterfall adalah sebagai berikut: 


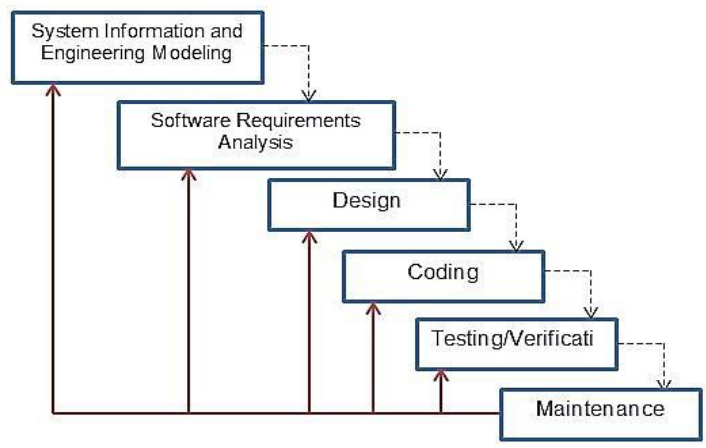

Gambar 1. Alur Hidup Waterfall

Keterangan menurut gambar di atas alur dari Model Waterfall sebagai berikut:

1. Rekayasa perangkat lunak (System Enginerring)

Melakukan pengumpulan data dan penetapan kebutuhan semua elemen sistem.

2. Requirements Analysis

Melakukan analisis terhadap permasalahan yang dihadapi dan menetapkan kebutuhan perangkat lunak, fungsi perform dan interfacing.

3. Design

Menetapkan domain informasi untuk perangkat lunak,fungi dan interfacing.

4. Coding (Implementasi)

Pengkodean yang mengimplementasikan hasil desain ke dalam kode atau bahasa yang dimengerti oleh mesin komputer dengan menggunakan bahasa pemprograman tertentu.

5. Testing (Pengujian)\

Kegiatan untuk melakukan pengetesan program yang sudah dibuat apakah sudah benar atau belum diuji dengan cara manual, jika testing sudah benar maka program boleh digunakan

6. Maintenance (Perawatan )

Menangani perangkat lunak yang sudah selesai supaya dapat berjalan lancar dan terhindar dari gangguan-gangguan yang dapat menyebabkan kerusakan.

\section{Pengujian}

Menurut Al Fatta ,H. (2007). Pengujian menggunakan metode Black box testing yang merupakan tipe testing yang memperlakukan perangkat lunak yang tidak diketahui kinerja internalnya. Sehingga para tester (penguji) memandang perangkat lunak seperti layaknya sebuah "kotak hitam" yang tidak penting dilihat isinya, tapi cukup dikenali proses testing dibagian luar teknik testing dalam black box.

\section{METODOLOGI PENELITIAN Metode Penelitian}

Metode penelitian yang digunakan dalam membangun Sistem Informasi Kredit Sahabat pada
BUMDes Sahabat Desa Semamung Berbasis web yaitu menggunakan metode kualitatif.

\section{Metode Pengembangan Sistem}

Metodologi Pengembangan Sistem adalah metode prosedur, konsep-konsep pekerjaan, aturan akan digunakan untuk mengembangkan suatu sistem informasi Pengembangan sistem didefinisikan sebagai sistem informasi berbasis komputer untuk menyelesaikan persoalan organisasi atau memanfaatkan kesempatan model air terjun (waterfall). Adapun proses yang dilakukan oleh penulis berdasarkan metode pengembangan perangkat lunak tersebut adalah sebagai berikut:

1. Rekayasa perangkat lunak (System Enginerring)

Pada tahap ini penulis melakukan pengumpulan data dengan melakukan observasi pada BUMDes Semamung dengan melihat pada buku besar dan penetapan kebutuhan data yang akan digunakan pada pembuatan sistem.

2. Requirements Analysis

Pada tahap ini penulis melakukan analisis terhadap permasalahan yang dihadapi oleh pihak manajemen BUMDes yaitu pada pencatatan peminjaman dan simpanan yang dilakukan oleh nasabah yang dilakukan secara manual dan menetapkan kebutuhan perangkat lunak, fungsi perform dan interfacing.

3. Design

Pada tahap ini menetapkan domain informasi untuk perangkat lunak yang akan dibuat yaitu dengan menitik beratkan pada desain dari sistem yang akan dibuat, serta fungi dari setiap halaman yang dibuat.

4. Coding (Implementasi)

Pada tahap ini adalah proses pengkodean yang mengimplementasikan hasil desain ke dalam kode atau bahasa pemrograman dengan menggunakan IDE sublime text dengan menggunakan bahasa pemprograman PHP dan database Mysq1.

5. Testing (Pengujian)

Pada tahap ini melakukan pengetesan atau uji coba program yang sudah dibuat, mencoba apakah semua fungsi berjalan sesuai prosedur yang ditentukan, jika testing sudah benar maka program boleh digunakan

6. Maintenance (Perawatan)

Pada tahap ini dilakukan proses penanganan perangkat lunak yang sudah selesai supaya dapat berjalan lancar dan terhindar dari gangguan-gangguan yang dapat menyebabkan kerusakan

\section{Alat dan Bahan Penelitian}

Alat penelitian yang digunakan dibagi menjadi tiga yaitu komponen perangkat keras, perangkat lunak dan pengguna sebagai pendukung penelitian yang dilakukan, 
alat ini yang akan dijadikan sebagai alat pengolahan data dan pembuatan sistem yang akan dirancang.

\section{Kebutuhan Perangkat}

Berdasarkan hasil dari tahapan yang dilakukan untuk merancang dan membuat Sistem Informasi Kredit Sahabat pada BUMDes Sahabat Desa Semamung diperlukan beberapa hal yang dilakukan yaitu

\section{a. Kebutuhan Perangkat Keras}

Perangkat keras yang dibutuhkan dalam pembuatan sistem informasi ini yaitu menggunakan komputer dengan spesifikasi sebagai berikut:

Tabel 1. Spesifikasi Perangkat Keras

\begin{tabular}{|l|l|}
\hline Nama Perangkat & Spesifikasi \\
\hline Laptop & Memori (RAM) 6.00 GB \\
\hline & Processor Intel Inside Core i5 \\
\hline & VGA NVIDIA GEFORCE \\
& $920 \mathrm{~m}$ \\
\hline & Harrdisk 500 gb \\
\hline
\end{tabular}

Spesifikasi tersebut disesuaikan dengan kebutuhan Sistem Informasi Kredit Sahabat pada BUMDes Sahabat Desa Semamung yang akan dibuat agar dapat menampung data lebih banyak sehingga komputer terhindar dari error saat memasukkan data dalam skala yang besar.

\section{b. Kebutuhan Perangkat Lunak}

Sistem Informasi Kredit Sahabat pada BUMDes Sahabat Desa Semamung sangat dibutuhkan karena dengan sistem ini proses pelaporan kredit sahabat dari nasabah yang berkunjung dapat dimonitoring sehingga laporan rekapitulasi data nasabah dapat di laporkan secara relevan dan akurat dan mengurangi kesalahan pendataan. Perangkat lunak yang di gunakan dalam pembuatan Sistem Informasi Kredit Sahabat ini adalah :

Tabel 2. Spesifikasi Perangkat Lunak

\begin{tabular}{|l|l|l|}
\hline No & $\begin{array}{l}\text { Perangkat } \\
\text { Lunak }\end{array}$ & \multicolumn{1}{|c|}{ Spesifikasi } \\
\hline 1. & $\begin{array}{l}\text { Windows 10 } \\
\text { Professional }\end{array}$ & $\begin{array}{l}\text { Digunakan untuk } \\
\text { menjalankan aplikasi yang } \\
\text { dibuat oleh pengembang. }\end{array}$ \\
\hline 2. & PHP & $\begin{array}{l}\text { Platform kerangka yang } \\
\text { digunakan membuat }\end{array}$ \\
\hline 3. & $\begin{array}{l}\text { Microsoft } \\
\text { Visio 2007 }\end{array}$ & $\begin{array}{l}\text { Digunakan seruk } \\
\text { perancangan Sistem seperti } \\
\text { pembuatan DFD dan } \\
\text { flowchart yang }\end{array}$ \\
\hline 4. & Xampp & $\begin{array}{l}\text { Menjadi server } \\
\text { digunakan untuk mengakses } \\
\text { MySQL. }\end{array}$ \\
\hline 5. & MySQL & $\begin{array}{l}\text { Digunakan untuk dalam } \\
\text { mengelola database seperti } \\
\text { menambahkan, mengubah, } \\
\text { dan menghapus data. }\end{array}$ \\
\hline
\end{tabular}

\section{c. Kebutuhan Pengguna}

Pengguna yang terlibat dalam sistem informasi beserta karakteristiknya yaitu bagian administrasi. Adapun kebutuhan dari pengguna tersebut terbagi dalam tugas dan hak asesnya di dalam sistem yang akan dibangun.

Tabel 3. Analisis Pengguna

\begin{tabular}{|l|l|l|}
\hline $\begin{array}{c}\text { Kategori } \\
\text { Pengguna }\end{array}$ & \multicolumn{1}{|c|}{ Tugas } & \multicolumn{1}{|c|}{ Hak Ases } \\
\hline Admin & $\begin{array}{l}\text { Mengelola melihat } \\
\text { dan mengatur Data } \\
\text { Master }\end{array}$ & $\begin{array}{l}\text { Menambah } \\
\text { mencari dan } \\
\text { mengedit data } \\
\text { login, data, }\end{array}$ \\
\cline { 2 - 3 } & Melihat data kredit & $\begin{array}{l}\text { Melihat data } \\
\text { registrasi dan data } \\
\text { pinjaman }\end{array}$ \\
\cline { 2 - 3 } & Membuat laporan & $\begin{array}{l}\text { Membuat laporan } \\
\text { dari data registrasi, } \\
\text { data transaksi. }\end{array}$ \\
\hline Manager & $\begin{array}{l}\text { Mengelola melihat } \\
\text { dan mengatur Data } \\
\text { Master }\end{array}$ & $\begin{array}{l}\text { Menambah } \\
\text { mencari } \\
\text { mengedit data, dan }\end{array}$ \\
\cline { 2 - 3 } & Melihat data kredit & $\begin{array}{l}\text { Melihat data } \\
\text { registrasi dan data } \\
\text { pinjaman }\end{array}$ \\
\cline { 2 - 4 } & Membuat laporan & $\begin{array}{l}\text { Membuat laporan } \\
\text { dari data registrasi, } \\
\text { data transaksi. }\end{array}$ \\
\hline Operator & $\begin{array}{l}\text { Pengajuan } \\
\text { Pinjaman }\end{array}$ & $\begin{array}{l}\text { Pinjaman kepada } \\
\text { admin dan manager }\end{array}$ \\
\hline
\end{tabular}

\section{Waktu dan Tempat Penelitian}

Adapun waktu dan tempat penelitian akan dijelaskan sebagai berikut :

\section{Tempat Penelitian}

Penelitian ini dilakukan di Badan Usaha Milik Desa Semamung yang berada di Wilayah Kecamatan Moyo Hulu. BUMDes ini mudah dijangkau karena berada di kantor desa. BUMDes yang beralamatkan di Jalan Lintas Sumbawa-Lunyuk ini memiliki tempat yang strategis sehingga banyak nasabah yang berkunjung ke tempat kantor desa tersebut. Untuk memperoleh data dan informasi terkait pembayaran kredit sahabat.

\section{HASIL DAN PEMBAHASAN}

\section{Rancangan Sistem Usulan}

Adapun rancangan sistem usulan yang akan dibuat adalah sebagai berikut:

\section{Flowmap Sistem yang diusulkan}

Adapun flowmap sistem yang diusulkan adalah sebagai berikut: 


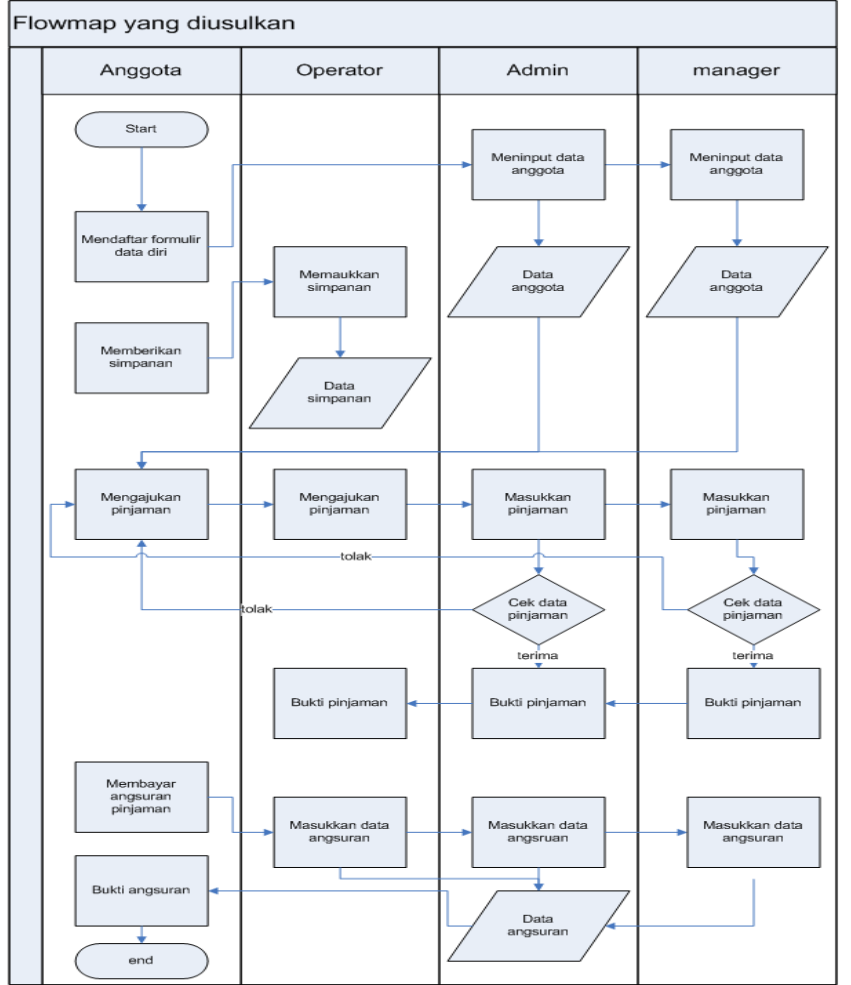

Gambar 2. Flowmap Proses Sedang Berjalan

Pada Gambar. 4.2 Flowmap menjelaskan bahwa anggota datang ke BUMDes untuk meminta permohonan menjadi anggota pada bagian pendaftaran yaitu operator BUMDes.

Prosedur Penyimpanan uang dilakukan oleh masyarakat yang telah menjadi anggotaMelalui operator sebagai pihak yang akan mengajukan pinjaman dengan memberikan pinjaman dengan jenis menengah yaitu pinjaman sebesar Rp.3.000.000,00 sedangkan pinjaman biasa yaitu pinjaman sebesar Rp.2.000.000,00 dan pinjaman full yaitu pinjaman sebesar Rp.5.000.000,00.

Admin atau manager dapat mengecek pinjaman yang telah diajukan apakah diterima atau ditolak. Jika sudah diterima maka dapat ditindak lanjuti untuk form pengajuan dicetak, kemudian ditandta tangan oleh anggota, admin dan manager. Kemudian diberikan dana sesuai dengan pinjamannya.

\section{Data Flow Diagram}

Adapun data flow diagram adalah sebagai berikut:

\section{a. Diagram Konteks}

Berikut diagram konteks dalam Sistem informasi

Kredit Sahabat pada BUMDes Sahabat Desa Semamung Berbasis web ini yaitu:

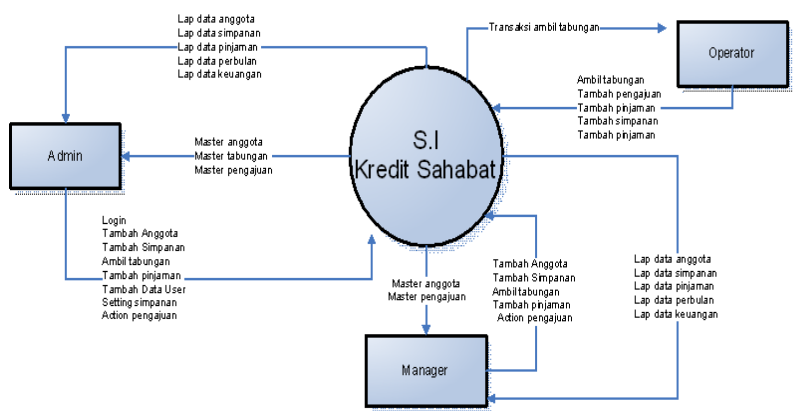

Gambar 3 Diagram Konteks

Diagram konteks di atas memberikan gambaran bahwa sistem dengan tiga terminal atau satuan luar, yaitu Admin, Operator dan Manager. Dengan proses utama yang dinamakan Sistem Informasi Kredit Sahabat. Tanda panah menunjukan masukan dan keluaran data. Data-data yang diinput nantinya akan digunakan untuk menjawab masukan atau sistem informasi yang diajukan oleh user terhaap sistem berupa kesimpulan yang diperlukan. Output yang dihasilkan sistem berupa jawaban dari informasi yang dimasukkan oleh admin berupa informasi data nasabah, data pinjaman dan data simpanan serta laporan dari proses yang dilakukan.

\section{b. Data Flow Diagram level}

Adapun data flow diagram dijabarkan sebagai berikut:

1. Data Flow Diagram Level 0

Adapun Data Flow Diagram Level 0 adalah sebagai berikut:

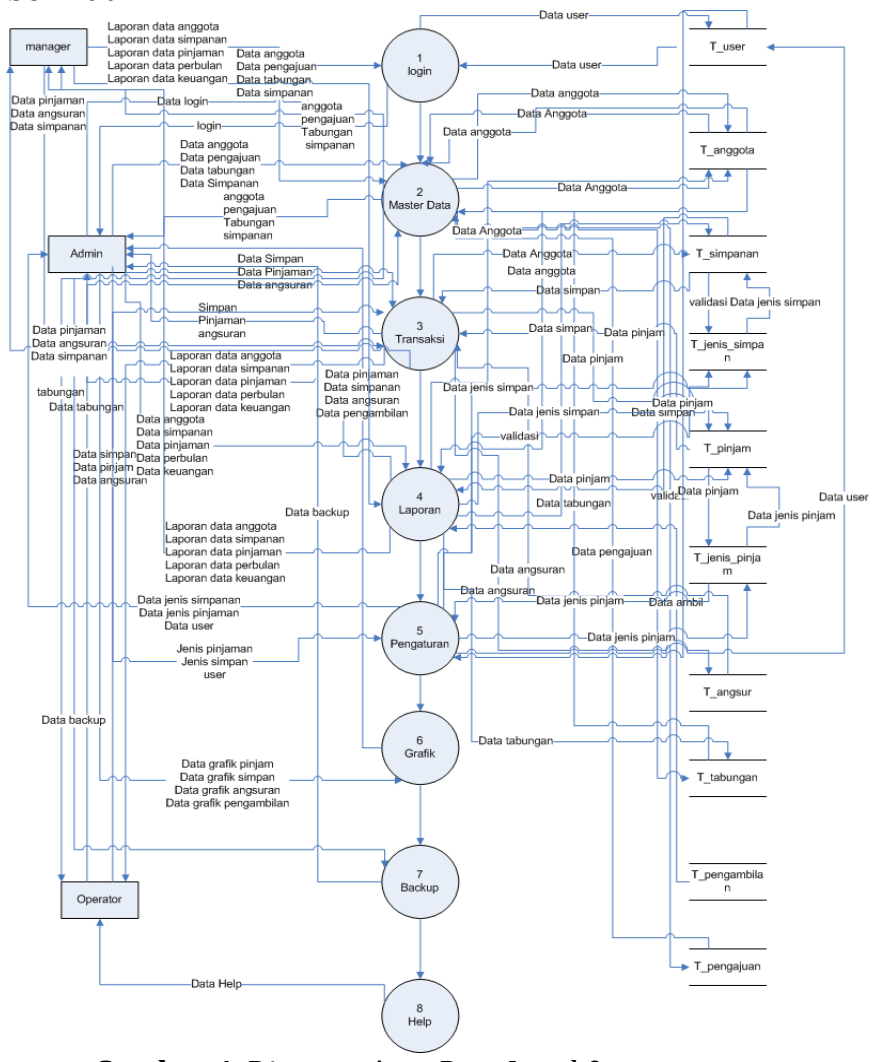

Gambar 4. Diagram Arus Data Level 0

Proses-proses yang terlibat adalah sebagai berikut: 
1. Login

Pada proses login ini terdapat tiga user yaitu Admin, Operator dan Manager.

2. Data Master

Pada proses data master terdapat tiga data yaitu data anggota, data tabungan,dan data pengajuan. Yang dapat mengakses ketiga data tersebut adalah admin, sedangkan untuk manager dapat melakukan proses tambah anggota dan pengajuan.

3. Transaksi

Pada proses transaksi ketiga user dapat melakukan proses ini dengan ketentuan operator mengajukan pinjaman, sedangkan admin dan manager dapat menyetujui pengajauan.

4. Laporan

Proses ini hanya dapat dilakukan oleh admin dan manager yang data tersebut diambil dari database sistem tersebut.

5. Pengaturan

Pada proses pengaturan terdapat mengatur data user oleh admin saja.

6. Grafik

Pada proses ini dapat dilihat grafik pinjaman, simpanan, angsuran dan pengambilan uang.

7. Backup

Pada proses ini dapat dilakukan backup data yang dapat dilakukan oleh admin.

8. Help sistem.

Pada proses ini hanya terlihat cara penggunaan

\section{Entity Relationship Diagram (ERD)}

Adapun perancangan ERD dari sistem tersebut adalah sebagai berikut;

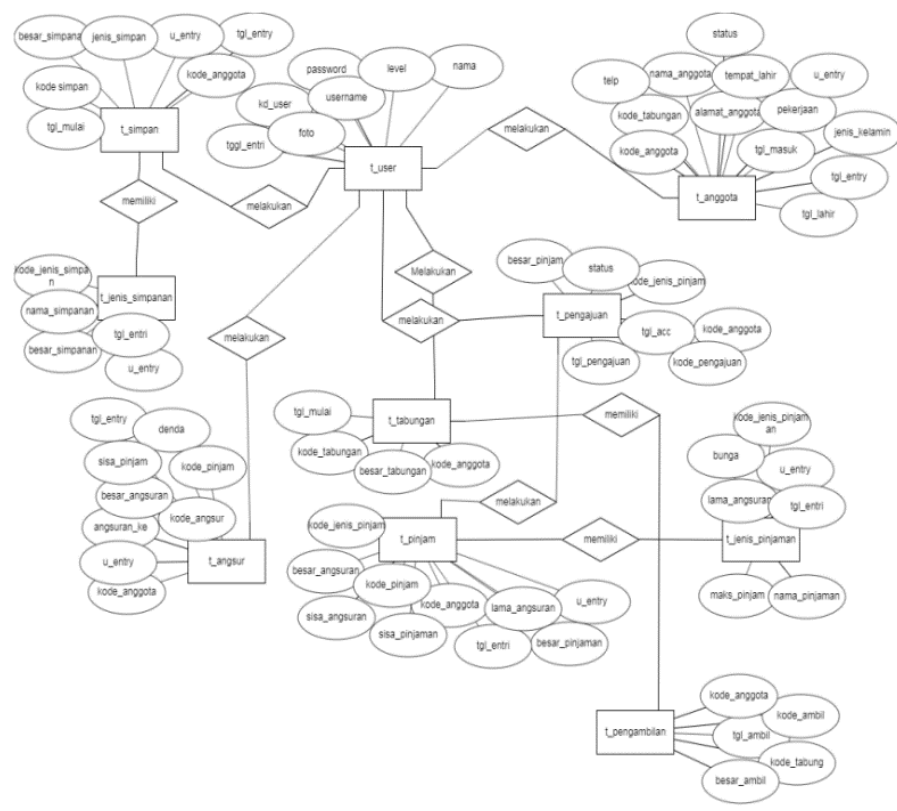

Gambar 5. ER Diagram

\section{Relasi Antar Tabel}

Relasi antar tabel adalah hubungan sebuah tabel dengan tabel lainnya. Adapun relasi antar tabel adalah sebagai berikut:

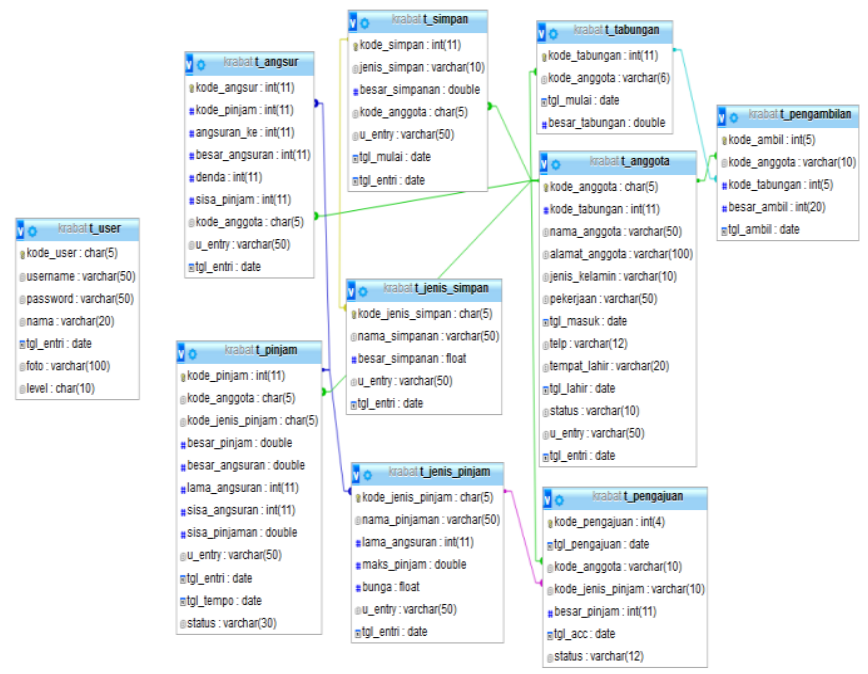

Gambar 6. Relasi Tabel

\section{Rancangan Tampilan}

Adapun rancangan tampilan pada sistem ini adalah sebagai berikut:

a. Login

Adapun tampilan menu login adalah sebagai berikut:

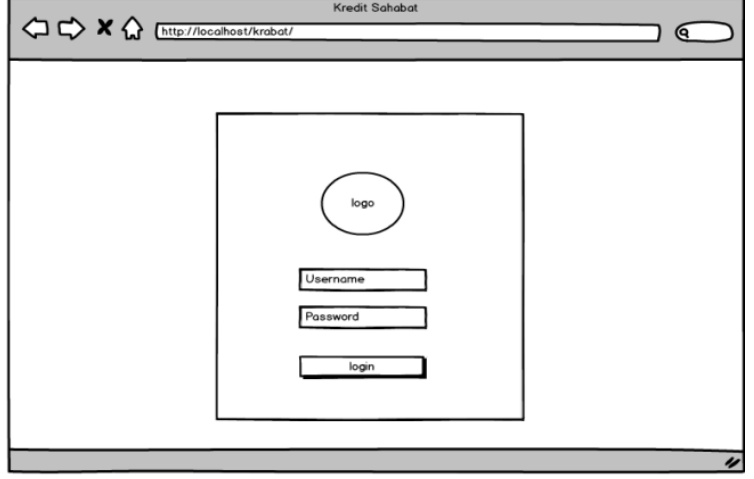

Gambar 7. Login

Pada menu login terdapat dua text field yaitu untuk memasukkan username dan password. Terdapat logo dari sistem yang dibuat dan terdapat satu button yang digunakan utuk login ke dalam sistem.

\section{Rancangan Tampilan Menu Dashboard User} berikut:

Tampilan menu dashboar user adalah sebagai
a. Dashboard Admin
Tampilan dashboard admin adalah sebagai berikut: 


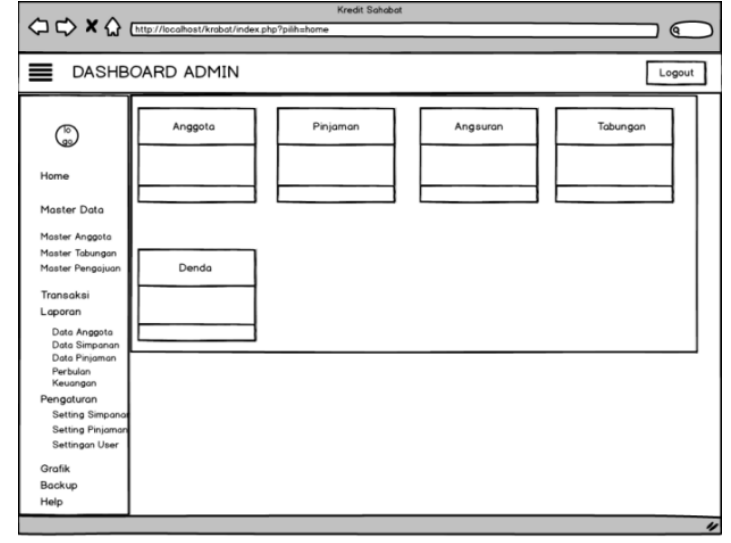

Gambar 8. Dashboard Admin

Pada menu Dashboard Admin ini terdapat dashboard yang terdapat berbagai menu yang dapat diklik.

b. Dashboard Manager

Tampilan dashboard Manager adalah sebagai berikut:

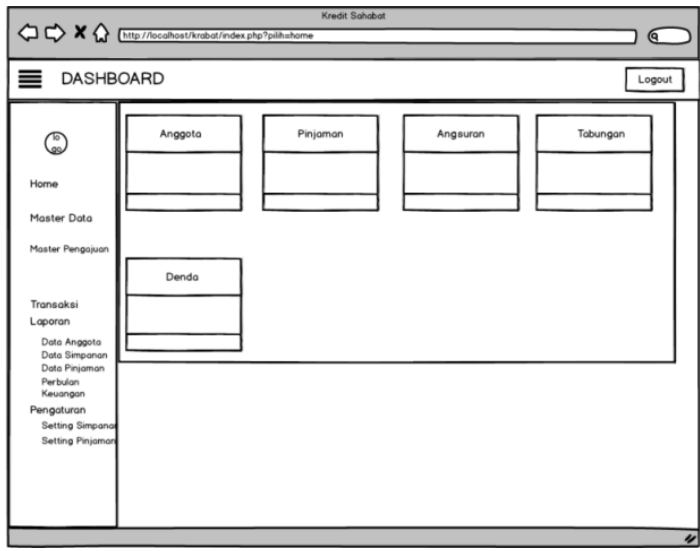

Gambar 9. Dashboard Manager

Pada menu Dashboard Manager ini terdapat dashboard yang terdapat berbagai menu yang dapat diklik. Di menu tersebut terdapat submenu seperti pada menu master data, laporan dan pengaturan yang menggunakan list menu.

c. Dashboard Operator

Tampilan dashboard operator adalah sebagai berikut:

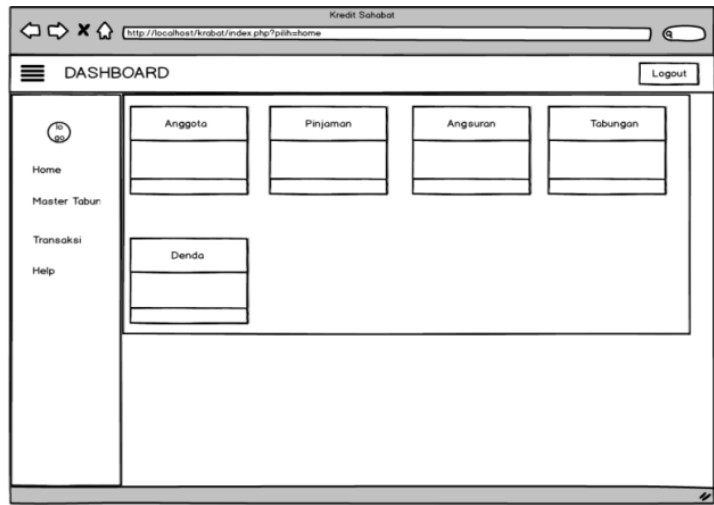

Gambar 10. Dashboard Operator
Pada menu Dashboard Operator ini terdapat dashboard yang terdapat berbagai menu yang dapat diklik.

\section{Implementasi Program}

Setelah melakukan perancangan sistem antar muka dengan menggunakan mockup, langkah selanjutnya adalah mengimplementasinya. Adapun tampilan dari sistem ini adalah sebagai berikut:

\section{Tampilan Menu Login}

Tampilan menu login sebagai berikut :

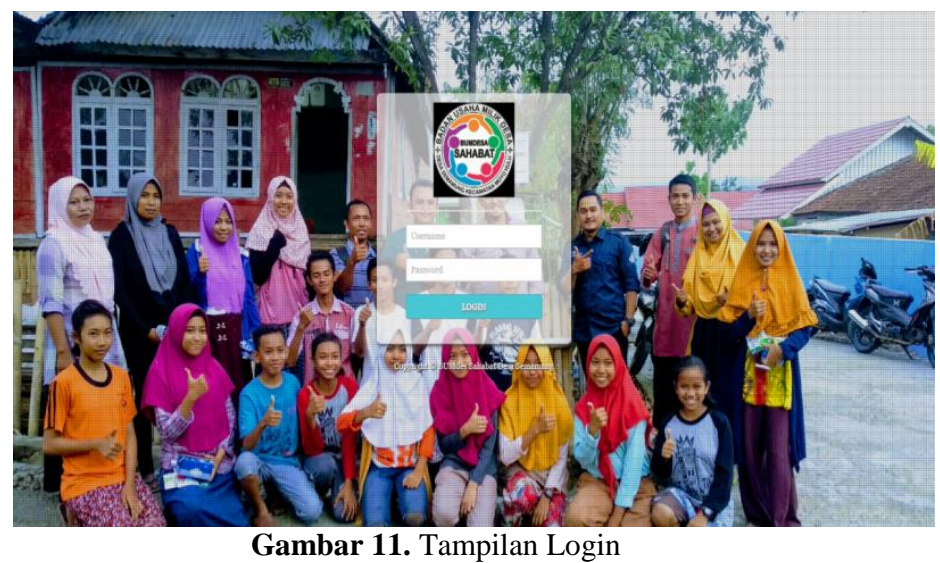

Pada halaman ini admin diminta untuk memasukkan user id dan password. Apabila proses tersebut berhasil maka muncul tampilan selanjutnya yaitu aplikasi berhasil dijalankan karena akses dapat diterima sehingga dapat masuk ke dalam menu utama.

\section{Implementasi Tampilan Menu Dashboard User}

Implementasi tampilan menu dashboar user adalah sebagai berikut:

a. Dashboard Admin

Adapun implementasi tampilan dashboard admin adalah sebagai berikut:

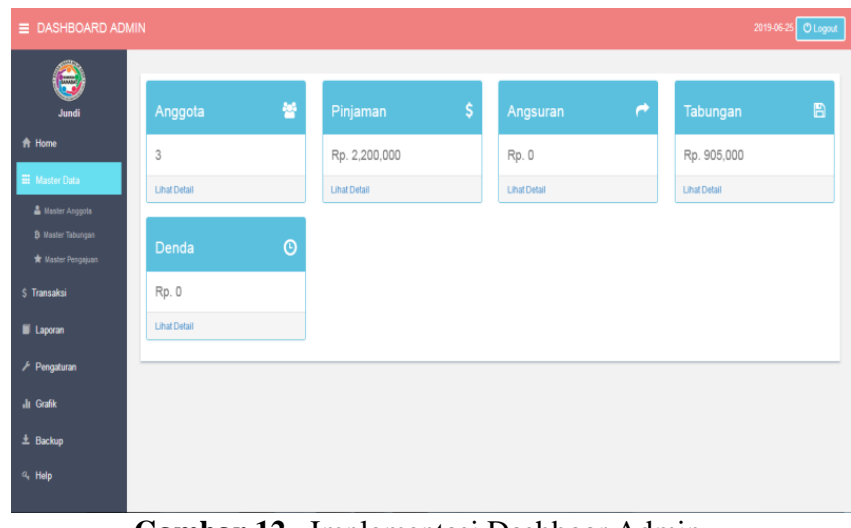

Gambar 12. Implementasi Dashboar Admin

Pada menu ini terdapat menu master data, transaksi, laporan, pengaturan, grafik, backup, dan help.

Adapun tampilan menu dashboard manager dan operator adalah sebagai berikut:

1. Manager 
Berikut adalah implementasi dari user Manager yaitu:

a. Menu dashboard

Tampilan menu dashboard manager adalah sebagai berikut:

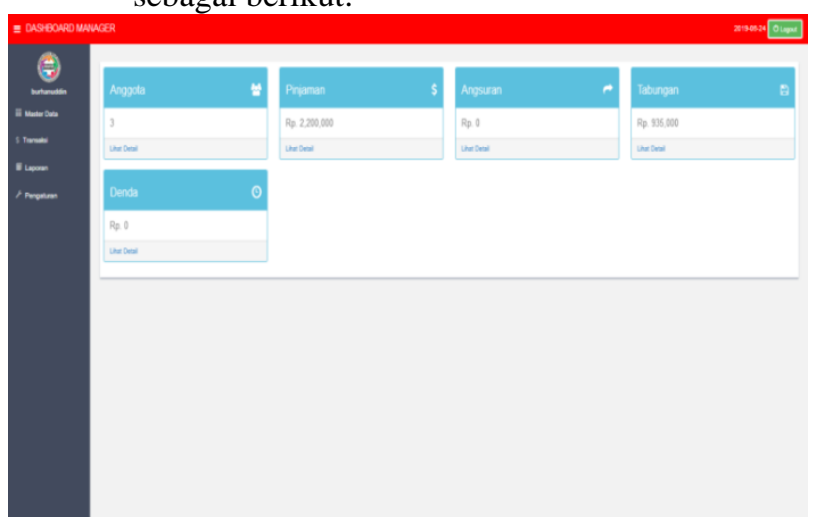

Gambar 13. Menu Dashboard Manager

Pada menu Dashboard Admin ini terdapat menu master data, transaksi, laporan, pengaturan, grafik, backup, dan help. berikut:

Adapun tampilan menu laporan adalah sebagai

a. Tampilan Laporan Data Anggota

Implementasi tampilan laporan data anggota adalah sebagai berikut:

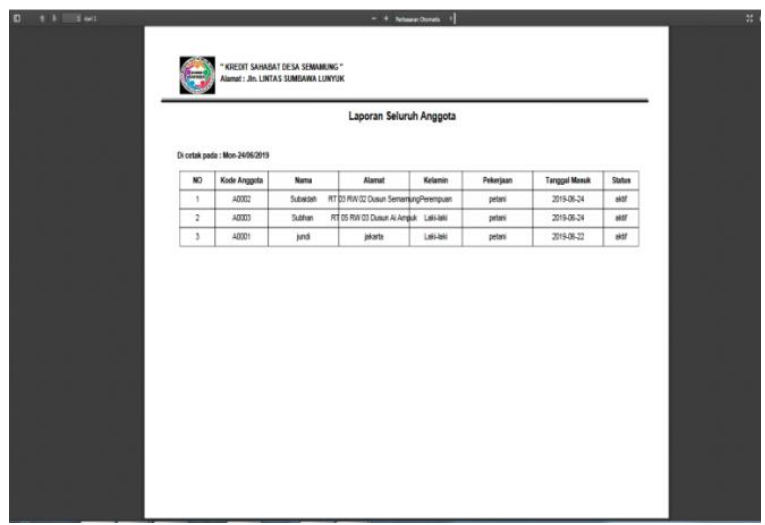

Gambar 14. Laporan Data Anggota

Pada menu ini terdapat aksi yaitu print data anggota yang telah dimasukkan sebagai laporan data anggota.

b. Laporan Pinjaman berikut:

Adapun proses print laporan adalah sebagai a

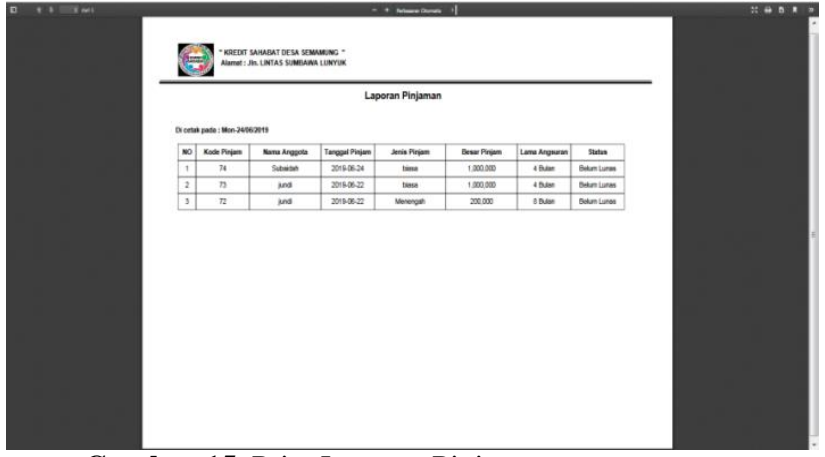

Gambar 15. Print Laporan Pinjaman

Pada menu ini terdapat aksi yaitu print data pinjaman yang telah dimasukkan sebagai laporan data pinjaman yang dapat dijadikan pdf maupun diprint lansung.

c. Laporan Pengajuan

Adapun menu selanjutnya adalah sebagai berikut:

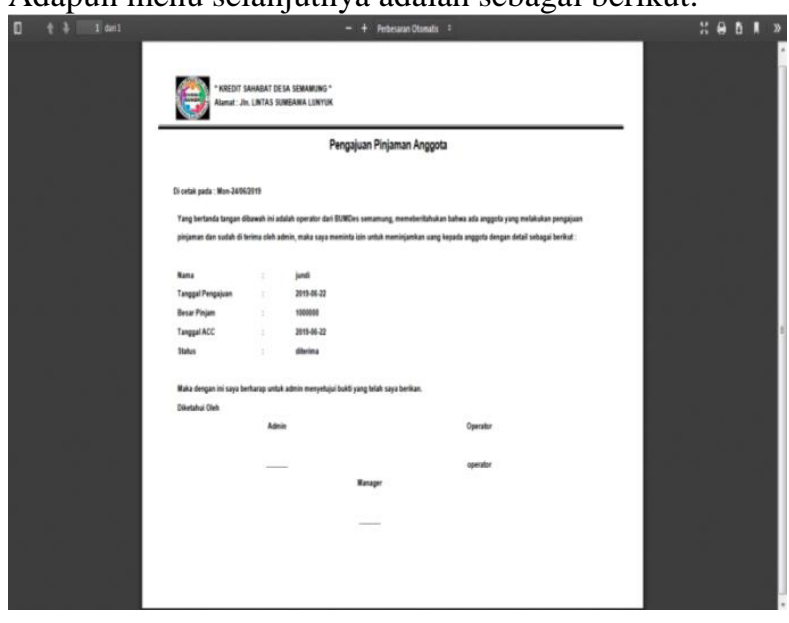

Gambar 16. Print Pengajuan Pinjaman

Pada menu ini dapat dilakukan print pengajuan yang akan ditanda tangai oleh admin, manager dan operator beserta foto copy Kartu Tanda Penduduk dan Kartu keluarga sebagai bukti bahwa anggota tersrbut melakukan pinjaman pada Kredit Sahabat (KRABAT).

\section{Pengujian}

Pengujian sistem yang penulis buat menggunakan blackbox testing untuk pengujian proses input dan outputnya saja. Adapun hasil pengujian adalah sebagai berikut:

\section{a. Login user (Operator, Admin, dan Manager) Pengujian pada menu login adalah sebagai berikut:}


Tabel 4. Pengujian Login

\begin{tabular}{|c|c|c|c|c|c|}
\hline No & $\begin{array}{l}\text { Skenaris } \\
\text { Rengujian. }\end{array}$ & Test Case & $\begin{array}{l}\text { Hasil Yang } \\
\text { Diharapkan }\end{array}$ & $\begin{array}{c}\text { Hasil } \\
\text { Pensujian }\end{array}$ & Kesimpulan \\
\hline 1 & $\begin{array}{l}\text { Mengesonglkan } \\
\text { semua isian data } \\
\text { login lalu } \\
\text { langsung } \\
\text { mengklikt tombol } \\
\text { login }\end{array}$ & $\begin{array}{l}\text { Username } \\
\text { :(keseng) } \\
\text { Password : } \\
\text { (keseng) }\end{array}$ & $\begin{array}{l}\text { Sistem alsan } \\
\text { menolak alsses } \\
\text { login dan } \\
\text { menampillkan } \\
\text { pesan"kolom } \\
\text { ini tidal beleh } \\
\text { keseng" }\end{array}$ & $\begin{array}{l}\text { sesuai } \\
\text { harapan }\end{array}$ & valid \\
\hline 2 & $\begin{array}{l}\text { Hanya mengisi } \\
\text { data } \\
\text { Username dan } \\
\text { mengesengkan } \\
\text { data } \\
\text { password lalu } \\
\text { langsung } \\
\text { mengllik. } \\
\text { tombol login }\end{array}$ & $\begin{array}{l}\text { Username: } \\
\text { Admin } \\
\text { Password: } \\
\text { (beseng) }\end{array}$ & $\begin{array}{l}\text { Sistem alkan } \\
\text { menolak akses } \\
\text { login dan } \\
\text { menampilkan } \\
\text { pesan"Kolem } \\
\text { Password } \\
\text { tidak beleh } \\
\text { keseng" }\end{array}$ & $\begin{array}{l}\text { sesuai. } \\
\text { harapan. }\end{array}$ & Valid \\
\hline 3. & $\begin{array}{l}\text { Hanya mensisi } \\
\text { data } \\
\text { password dan } \\
\text { mengosonglsan } \\
\text { data } \\
\text { username, lalu } \\
\text { langsung } \\
\text { mensklik } \\
\text { tombel login }\end{array}$ & $\begin{array}{l}\text { Username } \\
\text { :Admin } \\
\text { Password } \\
\text { :(keseng) }\end{array}$ & $\begin{array}{l}\text { Sistem alsan } \\
\text { menolak akses } \\
\text { login dan } \\
\text { menampillkan } \\
\text { pesan"kelom } \\
\text { Username } \\
\text { tidak beleh } \\
\text { kesong" }\end{array}$ & $\begin{array}{l}\text { sesuai } \\
\text { harapan }\end{array}$ & Valid \\
\hline 4 & $\begin{array}{l}\text { Mengimput data } \\
\text { login yang benar } \\
\text { lalu mengllilik } \\
\text { tombel "Login" }\end{array}$ & $\begin{array}{l}\text { Username } \\
\text { admin } \\
\text { Password } \\
\text { admin }\end{array}$ & $\begin{array}{l}\text { Sistem } \\
\text { menerima } \\
\text { alsses login } \\
\text { dan kemudian } \\
\text { langsung } \\
\text { menampillsan }\end{array}$ & $\begin{array}{l}\text { sesuai } \\
\text { harapan }\end{array}$ & valid \\
\hline
\end{tabular}

\section{KESIMPULAN DAN SARAN}

\section{Kesimpulan}

Berdasarkan proses analisis, pengujian dan implementasi dari perancangan sistem yang dibangun oleh penulis, maka dapat ditarik kesimpulan bahwa Sistem Informasi Kredit Sahabat pada BUMDes Sahabat Desa Semamung Berbasis web telah selesai dibangun menggunakan bahasa pemograman PHP dengan database MySql yang dapat mempermudah petugas dalam menjalankan proses pengajuan pinjaman atau kredit, simpanan, dan angsuran pada proses Kredit di BUMDes Sahabat Desa Semamung karena menggunakan sistem terkomputerisasi. Selain itu, sistem ini juga dapat mempermudah dalam penghitungan transaksi simpan pinjam secara otomatis dan proses penyusunan laporan dalam kegiatan simpan pinjam di BUMDes Sahabat Desa Semamung.

\section{Saran}

Adapun saran yang dapat disampaikan mengenai Sistem Informasi Kredit Sahabat pada BUMDes Sahabat Desa Semamung Berbasis web ini adalah adanya update apabila terdapat prosedur baru bagi masyarakat yang ingin menjadi anggota KRABAT yang berasal dari luar Desa Semamung sehingga cakupan web BUMDes lebih luas dan kredit berupa pinjaman barang yang dapat dilakukan selain dengan pinjaman uang saja.

\section{DAFTAR PUSTAKA}

.Al Fatta, H. (2007). Analisis dan Perancangan Sistem Informasi untuk keunggulan bersaing perusahaan dan organisasi modern. Penerbit Andi

Anhar, S. T. (2010). Panduan Menguasai PHP \& MySQL Secara Otodidak. Jakarta: Mediakita.21-22

D.P.M.D.(2017) Petunujuk Pedoman KREDIT SAHABAT Bagi Petani Miskin Melalui Badan Usaha Milik Desa Dalam Rangka Implementasi Program Desa Bebas Rentenir

Kadir, Abdul. (2014). "Pengenalan Sistem Informasi Edisi Revisi”. Yogyakarta: Penerbit Andi.

Muslihudin, M. (2016). Analisis Dan Perancangan Sistem Informasi Menggunakan Model Terstruktur Dan UML. Penerbit Andi.

Pembangunan, P. K. D. S. (2007). Buku Panduan Pendirian dan Pengelolaan Badan Usaha Milik Desa (BUMDes). Malang: Fakultas Ekonomi Universitas Brawijaya.

Sutabri, Tata. 2012. Konsep Sistem Informasi. Yogyakarta: Andi

Sutanta, Edhy. 2011. Sistem Informasi Manajemen. Yogyakarta : Andi 